\title{
Picoalgae in Danish coastal waters during summer stratification
}

\author{
Morten Søndergaard ${ }^{1}$, Lillian M. Jensen ${ }^{2}$, Gunni Ertebjerg ${ }^{3}$ \\ ${ }^{1}$ Freshwater Biological Laboratory, University of Copenhagen, 51 Helsingørsgade, DK-3400 Hillerød, Denmark \\ ${ }^{2}$ Institute of Life Sciences and Chemistry, Roskilde University, PO Box 260, DK-4000 Roskilde, Denmark \\ ${ }^{3}$ National Environmental Research Institute, Division of Marine Ecology and Microbiology, 399 Frederiksborgvej, \\ PO Box 358, DK-4000 Roskilde, Denmark
}

\begin{abstract}
The abundance and relative importance of picoalgae (autotrophic picoplankton, APP) were surveyed in Danish marine waters during summer stratification to test the hypothesis of high APP importance under oligotrophy. A picoalgal community dominated by Synechococcus was found at 28 of

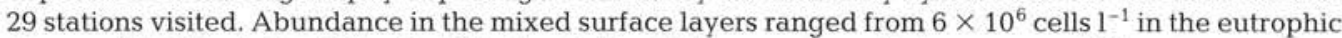
German Bight to $4.5 \times 10^{8}$ cells $1^{-1}$ in the Baltic. Differences in cell sizes among different areas were also found. Total APP biovolumes and $<2 \mu \mathrm{m}$ fractionated chlorophyll concentrations showed no relationship; consequently the APP biomass as indicated by chlorophyll was calculated from the biovolume estimates. High relative APP importance was negatively related to total chlorophyll. A power function with an exponent close to -1 showed the best model of the relative importance. However, an analysis of the APP chlorophyll values in the mixed surface waters showed a constant biomass of 0.5 to $0.6 \mu \mathrm{g} \mathrm{chl} 1^{-1}$, although with a trend for higher values in the Baltic and lower values in the German Bight. Thus, picoalgal biomass could be considered constant over the entire range of total chlorophyll, and increases in total autotrophic biomass were mainly due to increases in the nanoplankton.
\end{abstract}

\section{INTRODUCTION}

The importance of autotrophic picoplankton (APP) to phytoplankton biomass in marine and freshwater ecosystems has been extensively documented in recent years (Fogg 1986, Stockner \& Antia 1986, Søndergaard 1991). In offshore oceanic areas usually 50 to $90 \%$ of the chlorophyll is found in particles $<2.0 \mu \mathrm{m}$ (Stockner 1988), whereas a lower contribution, but often higher cell numbers, are observed in more eutrophic coastal areas (Takahashi et al. 1985, Jochem 1988, Olson et al. 1990). The abundance of picoalgal cells is most often between $10^{6} 1^{-1}$ in the most oligotrophic oceans to summer peaks of $10^{8} 1^{-1}$ in more productive areas (El Hag \& Fogg 1986, Joint 1986, Olson et al. 1990).

The high relative importance of APP in areas with low nutrient input and during prolonged stratification periods with dominance of regenerated production (El Hag \& Fogg 1986, Joint 1986, Cushing 1989) is in accordance with the hypothesis of enhancement of the microbial loop under such conditions (Azam et al. 1983). A similar negative relationship between impor- tance of APP and primary productivity has been demonstrated in temperate lakes (Søndergaard 1991). The dominance of picoalgae under oligotrophic conditions could relate to the ability of small cells to compete successfully at very low nutrient concentrations (Raven 1986). Furthermore, in a survey of the size distribution of chlorophyll in oceanic areas and the Mediterranean Sea, Raimbault et al. (1988) found the picoalgal fraction $(<3 \mu \mathrm{m})$ never to exceed $1.3 \mu \mathrm{g} \mathrm{chl} \mathrm{l^{-1 }}$ and to be constant over a wide range of total chlorophyll concentrations. Consequently it can be hypothesized that picoalgal biomass is not regulated by nutrients, a conclusion also reached by Kuosa (1991) from a study in the northern Baltic Sea. Transient inputs of nutrients mainly creates responses in new production by the larger algal size classes (Cushing 1989, Kiørboe \& Nielsen 1990).

Although many different taxonomic groups have members within the commonly accepted APP size $(<2.0 \mu \mathrm{m}$ in longest dimension; Sieburth et al, 1978, Stockner \& Antia 1986) the cyanobacterium Synechococcus is the most important genus and the dominant 
APP in oceanic waters. Eukaryotes and prochlorophytes have been recorded (Joint 1986, Chisholm et al. 1988, Wood \& Søndergaard unpubl.), however the only published record of eukaryote APP dominance in the marine environment is by Hall \& Vincent (1990) in the Tasman Sea. Eukaryotes are most often outnumbered by the cyanobacteria by an order of magnitude in oceanic situations, but their contribution seems higher and more variable in coastal waters (Glover et al. 1988) and lakes (Søndergaard 1991).

In the present investigation we examined, within a short period, picoalgal abundance in most Danish coastal areas: the Kattegat, Skagerrak, North Sea including German Bight, Belt Sea and Baltic proper (Arkona Sea) (Fig. 1). Previous investigations of picoalgae within this area and the Baltic proper have been rather few and restricted with respect to spatial coverage. In the Baltic proper and Kiel Bight summer peaks of cyanobacterial picoalgae were about $2 \times 10^{8} 1^{-1}$ in surface waters (Jochem 1988, Kuosa 1988) with occasional brief subsurface peaks of $1.6 \times 10^{9} \mathrm{I}^{-1}$ (Kuosa 1990, 1991). In July 1989 surface samples from the western Baltic, the Belt Sea and the Kattegat had Synechococcus abundances from 2.9 to $5.1 \times 10^{7} 1^{-1}$ (Buck et al. unpubl.) representing between 2 and $14 \%$ of the total autotrophic biomass.

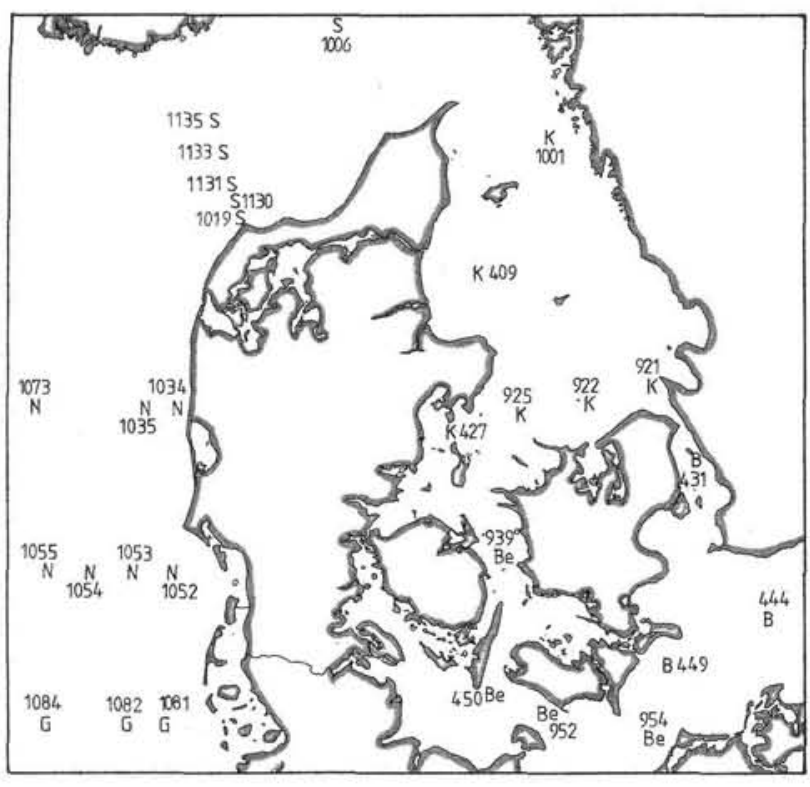

Fig. 1. Danish coastal areas with sampling stations. $K=$ Kattegat, $\mathrm{S}=$ Skagerrak, $\mathrm{N}=$ North $\mathrm{Sea}, \mathrm{G}=$ German Bight, $\mathrm{Be}=$ Belt Sea, B = Baltic proper (Arkona Sea and Øresund)

The coastal waters around Denmark have complex hydrodynamics with respect to salinity, mixing depth, nutrient loading and frontal systems (Svansson 1984, Kiørboe et al. 1990). Thus, during a summer situation with potentially high APP numbers it should be possible to investigate the hypothesis that the relative dominance of picoalgae is related to low nutrient input and low algal biomass (Takahashi et al. 1985, Olson et al. 1990) and that a constant picoalgal biomass prevails over a wide range of algal biomass (Raimbault et al. 1988).

\section{MATERIAL AND METHODS}

Study sites. Sampling was conducted from 12 to 23 August 1990 during a cruise covering all Danish coastal areas. Sites with station numbers are shown in Fig. 1. The exact positions are available on request. In the present context 5 main areas are recognized:

(1) Kattegat, Stns 921, 922, 925, 427, 409 and 1001;

(2) Skagerrak, Stns 1006, 1135, 1133, 1131, 1130 and 1019 ;

(3) North Sea, Stns 1073, 1035, 1034, 1055-1052 and the German Bight transect 1084-1081;

(4) Belt Sea, Stns 939, 450, 952, 954;

(5) Baltic Sea, Stns 449, 444 and 431 (431 is categorized here due to low salinity).

The water masses were characterized by salinity, inorganic nitrogen, inorganic phosphorous, total chlorophyll and mixing depth (Table 1).

Water samples were taken with a rosette sampler (51 Niskin bottles) with continuous CTD monitoring. We used a sampling strategy with depth-integrated samples of equal volume from the mixed layer (4 depths in the Skagerrak and the North Sea and 5 depths at all other stations), some selected samples from the pycno- or thermocline, and in a few cases samples from greater depths.

Nutrients and total chlorophyll were measured immediately aboard ship. The nutrients were measured on autoanalyzer according to the guidelines of Grasshoff et al. (1983). The detection limits of ammonia, nitrite, nitrate and reactive phosphate were $0.06,0.03$, 0.06 and $0.09 \mu \mathrm{mol} \mathrm{l}^{-1}$, respectively. Total chlorophyll was measured according to Helsinki Commission (1988) guidelines. The distribution of chlorophyll among micro-, nano- and picoplankton fractions (Sieburth et al. 1978) was determined by serial filtration through $20 \mu \mathrm{m}$ pore size nylon net and 2.0 and $0.2 \mu \mathrm{m}$ Nuclepore filters. After extraction of the nets and filters in $96 \%$ ethanol (Jespersen \& Christoffersen 1987) the concentration of chlorophyll was measured by fluorometry.

Autotrophic picoplankton. Samples for microscopic examination of APP were prepared immediately by pre-screening through a $20 \mu \mathrm{m}$ pore size net to remove large particles and then harvesting all particles from $20 \mathrm{ml}$ on black-stained $0.2 \mu \mathrm{m}$ Nuclepore filters. The 
Table 1. Hydrographic and nutrient data from August 1990, Cruise 94. Mixing depth is based on density differences. IN: inorganic nitrogen $\left(\mathrm{NO}_{3}+\mathrm{NO}_{2}+\mathrm{NH}_{4}\right)$ in mixed layer; IP: soluble reactive phosphorus in mixed layer

\begin{tabular}{|c|c|c|c|c|c|c|c|}
\hline Station & $\begin{array}{l}\text { Temp. } \\
\left({ }^{\circ} \mathrm{C}\right)\end{array}$ & $\underset{(\%)}{S}$ & $\begin{array}{l}\text { Mixing } \\
\text { depth } \\
\text { (m) }\end{array}$ & $\begin{array}{l}\text { Nitricline } \\
\text { depth } \\
\text { (m) }\end{array}$ & $\begin{array}{c}\text { IN } \\
\left(\mu \mathrm{mol} \mathrm{I}^{-1}\right)\end{array}$ & $\begin{array}{c}\text { IP } \\
\left(\mu \mathrm{mol} 1^{-1}\right)\end{array}$ & $\begin{array}{c}\mathrm{Chl} \\
\left(\mu \mathrm{g} \mathrm{l}^{-1}\right)\end{array}$ \\
\hline \multicolumn{8}{|c|}{ Kattegat } \\
\hline 921 & 18.8 & 15.0 & 10 & 12 & $<0.03$ & 0.20 & 1.50 \\
\hline 922 & 19.0 & 18.4 & 12 & 18 & $<0.03$ & 0.05 & 0.91 \\
\hline 925 & 17.8 & 18.6 & 10 & 12 & 0.3 & 0.31 & 1.21 \\
\hline 427 & 17.2 & 17.7 & 12 & 35 & $<0.03$ & 0.23 & 4.29 \\
\hline 409 & 18.3 & 20.5 & 8 & - & 1.0 & 0.07 & 1.65 \\
\hline 1001 & 19.3 & 24.4 & 12 & 40 & $<0.03$ & 0.35 & 1.31 \\
\hline \multicolumn{8}{|c|}{ Skagerrak } \\
\hline 1006 & 18.2 & 28.3 & 8 & 35 & $<0.03$ & $<0.05$ & 6.99 \\
\hline 1135 & 18.5 & 27.7 & 8 & 40 & $<0.03$ & $<0.05$ & 0.52 \\
\hline 1133 & 17.6 & 31.7 & 23 & 35 & $<0.03$ & $<0.05$ & 0.24 \\
\hline 1131 & 16.8 & 32.3 & TM & - & $<0.03$ & $<0.05$ & 0.20 \\
\hline 1130 & 16.8 & 31.9 & TM & - & $<0.03$ & $<0.05$ & 0.22 \\
\hline 1019 & 17.1 & 32.0 & TM & - & $<0.03$ & $<0.05$ & 0.83 \\
\hline \multicolumn{8}{|c|}{ North Sea } \\
\hline 1073 & 17.2 & 31.9 & 17 & - & $<0.03$ & $<0.05$ & 0.59 \\
\hline 1035 & 17.4 & 32.8 & TM & - & $<0.03$ & $<0.05$ & 1.86 \\
\hline 1034 & 18.1 & 33.3 & TM & - & $<0.03$ & 0.07 & 5.98 \\
\hline 1055 & 16.7 & 33.8 & TM & - & 0.35 & 0.05 & 3.30 \\
\hline 1054 & 17.0 & 33.6 & TM & - & $<0.03$ & $<0.05$ & 5.61 \\
\hline 1053 & 17.3 & 33.3 & TM & - & $<0.03$ & 0.16 & 10.11 \\
\hline 1052 & 17.9 & 32.5 & TM & - & 0.25 & 0.49 & 7.61 \\
\hline 1084 & 17.1 & 33.8 & TM & - & $<0.03$ & 0.15 & 1.87 \\
\hline 1082 & 17.5 & 32.5 & TM & - & $<0.03$ & 0.05 & 9.52 \\
\hline 1081 & 18.0 & 31.6 & TM & - & 0.48 & 0.20 & 18.16 \\
\hline \multicolumn{8}{|c|}{ Belt Sea, Baltic } \\
\hline 939 & 17.0 & 15.5 & 8 & 12 & 0.05 & 0.42 & 4.87 \\
\hline 450 & 16.5 & 15.3 & 16 & 18 & 0.35 & 0.46 & 3.42 \\
\hline 952 & 17.0 & 13.3 & 16 & 20 & $<0.03$ & 0.27 & 4.74 \\
\hline 954 & 17.3 & 10.2 & 15 & 20 & 0.03 & 0.17 & 6.72 \\
\hline 449 & 14.7 & 8.8 & 16 & 18 & 0.06 & 0.43 & 2.67 \\
\hline 444 & 15.6 & 8.0 & 8 & 15 & 0.04 & 0.33 & 1.91 \\
\hline 431 & 17.8 & 10.2 & 12 & 12 & 0.21 & 0.42 & 3.66 \\
\hline
\end{tabular}

filters were mounted in low fluorescent immersion oil and kept frozen until microscopic examination within a month. A pre-filtration through $2.0 \mu \mathrm{m}$ filters was avoided due to generally low particle densities and low masking probability, and to eliminate the risk of APP retainment on filters. Glutaraldehyde-fixed samples $(0.5 \% \mathrm{v} / \mathrm{v})$ were taken in parallel and kept for later examination of heterotrophic bacteria and APP. The procedure with unfixed samples and frozen slide preparations proved satisfactory compared with the fixed samples. The literature concerning fixatives and sample storage is somewhat conflicting. Loss of chlorophyll a fluorescence and serious underestimation of eukaryotic APP abundance using glutaraldehyde fixation was found by Hall (1991), while others have identified this fixative to be appropriate (Booth 1987, Kuuppo-Leinikki \& Kuosa 1989). In a previous comparison of APP cell counts from lakes and the Medi- terranean Sea the procedure used in this investigation did not show significantly less cells than a procedure where samples were prepared and counted immediately. However, in light of the findings by Hall (1991), an underestimation of eukaryote APP cells cannot be ruled out.

Phototrophic organisms were visualized by their characteristic autofluorescence at blue and green excitation with an epifluorescent microscope (Waterbury et al. 1979, Caron 1983). The Olympus HB2 (tubus factor 1.25) was equipped with standard blue and green filter combinations (Søndergaard 1991), $10 \times$ calibrated ocular and a $100 \times$ plan apochromate objective $(\mathrm{NA}=1.40)$ giving a final magnification of $1250 \times$. Although green excitation provides the best emission picture of cyanobacteria, blue is better suited for distinguishing between cyanobacteria and eukaryotes. The presence of a chloroplast and red emission is 
used as the eukaryote criterium in this study as opposed to the bright (or sometimes pale) yellow/orange emission by cyanobacteria (Caron et al. 1985).

When possible a total of 300 to 400 cyanobacterial cells were counted. Due to low abundance only 30 to 100 eukaryote cells could be counted in most cases. The sizes of the picoalgae were estimated to the nearest $0.1 \mu \mathrm{m}$ with a New Porton grid (May 1965) built into a $10 \times$ ocular. The sizes were later confirmed from enlarged micrographs. Biovolumes were calculated as spheres or rods. Because an evaluation of the importance of the picoalgae is normally based on their contribution to autotrophic biomass, the estimations of size and biovolume are essential due to problems with size-fractionated chlorophyll measurements (Craig 1986, Søndergaard 1991, this study).

Picoalgal biomass. APP biovolumes were converted to chlorophyll using 220 and $250 \mathrm{fg}$ cell $\mathrm{C} \mu \mathrm{m}^{-3}$ for eukaryotes and cyanobacteria, respectively (Kana \& Glibert 1987, Booth 1988), and a carbon: chlorophyll ratio of 22.5 (Takahashi et al. 1985, Geider 1987, Ray et al. 1989). It should be emphasized that these factors are not constants and that different conversion factors have been used by other authors (e.g. Kuosa 1988). However, the chlorophyll estimates obtained using the above factors did not change significantly when applying factors used by Waterbury et al. (1986). The successfull comparison of APP biovolume with measured chlorophyll by Li \& Wood (1988) suggested that the factors chosen here should provide reasonably reliable results.
In a recent study of freshwater picoalgae it was suggested that a major disagreement between measured and calculated APP chlorophyll was due to an overestimation of the chlorophyll concentrations in the $<2.0 \mu \mathrm{m}$ size fraction (Søndergaard 1991). The procedure in this study provided an opportunity to compare the 2 approaches: directly measured chlorophyll from size fractionated samples versus calculated values. The pooled data from all samples showed the measured APP chlorophyll to average $50 \%$ of total chlorophyll (summation of fractionated samples), while the calculated APP chlorophyll averaged only $12 \%$ of the total. Thus, the measured APP chlorophyll values were about 3.5 times the calculated values. As a correlation between measured APP chlorophyll and biovolume proved insignificant $(\mathrm{r}=0.14)$, the APP chlorophyll concentrations based on serial filtration are concluded to be erroneous. Accordingly, calculated picoalgal chlorophyll concentrations are used in this presentation. The reliability of the chosen conversion factors is further supported by the fact that the chlorophyll:volume ratio used of about 11 is in accordance with the ratio of about 10 that can be calculated from the data presented by Hall \& Vincent (1990).

\section{RESULTS}

Picoalgal abundance in the mixed layer ranged from

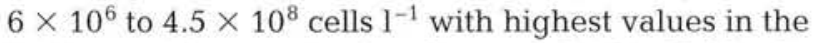
Baltic and lowest in the German Bight (Table 2).

Table 2. Distribution, abundance and biovolume of prokaryote (P) and eukaryote (E) picoalgae in depth-integrated surface samples (Int) and at given depths ( $\mathrm{m}$ ) in Danish coastal waters. Absence of $\mathrm{E}$ in any given sample means that eukaryotes were not found. Percentage of prokaryotes to total picoalgal biovolume and relative picoalgal contribution to total chlorophyll ( $\left.\mathrm{CHL}_{t}\right)$ are also included

\begin{tabular}{|c|c|c|c|c|c|c|}
\hline $\begin{array}{l}\text { Station, } \\
\text { cell type }\end{array}$ & depth, & $\begin{array}{l}\text { Abundance } \\
\left(10^{6} \text { cells } 1^{-1}\right)\end{array}$ & $\begin{array}{c}\text { Biovolume } \\
\left(\mu \mathrm{m}^{3} \text { cell } 1^{-1}\right)\end{array}$ & $\begin{array}{l}\text { Total biovolume } \\
\left(10^{6} \mu \mathrm{m}^{3} \mathrm{I}^{-1}\right)\end{array}$ & $\begin{array}{c}P: E+P \\
(\%)\end{array}$ & $\begin{array}{c}\text { APP } \\
\left(\% \text { of } \mathrm{CHL}_{t}\right)\end{array}$ \\
\hline \multicolumn{7}{|l|}{ Kattegat } \\
\hline \multirow{2}{*}{$921 \mathrm{lnt}$} & $\mathrm{P}$ & 88 & 0.45 & 39.6 & 93 & 22 \\
\hline & E & 3.8 & 0.80 & 3.0 & - & - \\
\hline \multirow{2}{*}{18} & $\mathrm{P}$ & 4 & 0.36 & 1.4 & 78 & - \\
\hline & E & 0.5 & 0.80 & 0.4 & - & - \\
\hline \multirow{3}{*}{$\begin{array}{r}922 \text { Int } \\
23\end{array}$} & $\mathrm{P}$ & 102 & 0.52 & 53.0 & 100 & 60 \\
\hline & $\mathrm{P}$ & 16 & 0.70 & 11.2 & 97 & - \\
\hline & E & 0.4 & 0.80 & 0.3 & - & - \\
\hline \multirow[t]{2}{*}{925 Int } & $\mathrm{P}$ & 93 & 0.38 & 35.3 & 86 & 30 \\
\hline & E & 0.4 & 1.15 & 0.5 & - & - \\
\hline 18 & $\mathrm{P}$ & 7 & 0.80 & 5.6 & 100 & - \\
\hline \multirow{3}{*}{$\begin{array}{r}427 \text { Int } \\
18\end{array}$} & $\mathrm{P}$ & 107 & 0.45 & 48.2 & 100 & 12 \\
\hline & $\mathrm{P}$ & 44 & 0.90 & 39.6 & 99 & - \\
\hline & E & 0.2 & 2.10 & 0.4 & - & \\
\hline \multirow[t]{2}{*}{409 Int } & $\mathrm{P}$ & 101 & 0.38 & 38.4 & 97 & 25 \\
\hline & $\mathrm{E}$ & 1.6 & 0.70 & 1.1 & - & - \\
\hline $1001 \mathrm{Int}$ & $\mathrm{P}$ & 55 & 0.52 & 28.6 & 100 & 22 \\
\hline
\end{tabular}


Table 2 (continued)

\begin{tabular}{|c|c|c|c|c|c|c|}
\hline \multicolumn{2}{|c|}{$\begin{array}{l}\text { Station, depth, } \\
\text { cell type }\end{array}$} & $\begin{array}{c}\text { Abundance } \\
\left(10^{6}{\left.\text { cells } 1^{-1}\right)}^{-1}\right.\end{array}$ & $\begin{array}{c}\text { Biovolume } \\
\left(\mu \mathrm{m}^{3} \text { cell } 1^{-1}\right)\end{array}$ & $\begin{array}{l}\text { Total biovolume } \\
\left(10^{6} \mu \mathrm{m}^{3} 1^{-1}\right)\end{array}$ & $\begin{array}{c}P: E+P \\
(\%)\end{array}$ & $\begin{array}{c}\text { APP } \\
\left(\% \text { of } \mathrm{CHL}_{t}\right)\end{array}$ \\
\hline \multicolumn{7}{|c|}{ Skagerrak } \\
\hline \multirow[t]{2}{*}{$1006 \mathrm{Int}$} & & 110 & 0.38 & 41.8 & 99 & 7 \\
\hline & E & 0.65 & 0.52 & 0.3 & - & - \\
\hline 5 & $\mathrm{P}$ & 115 & 0.27 & 31.1 & 100 & - \\
\hline \multirow[t]{2}{*}{25} & $\mathrm{P}$ & 13 & 0.70 & 9.1 & 88 & - \\
\hline & E & 0.85 & 1.44 & 1.2 & - & - \\
\hline 50 & $\mathrm{P}$ & 2 & 2.0 & 4.0 & 100 & - \\
\hline \multirow[t]{2}{*}{$1135 \mathrm{Int}$} & $\mathrm{P}$ & 83 & 0.27 & 22.4 & 97 & 46 \\
\hline & E & 0.6 & 1.15 & 0.7 & - & - \\
\hline \multirow[t]{2}{*}{25} & $\mathrm{P}$ & 77 & 0.27 & 20.8 & 82 & - \\
\hline & $\mathrm{E}$ & 3.9 & 1.15 & 4.5 & - & - \\
\hline \multirow{2}{*}{$\begin{array}{r}1133 \text { Int } \\
30\end{array}$} & $\mathrm{P}$ & 80 & 0.27 & 21.6 & 100 & 96 \\
\hline & $\mathrm{P}$ & 21 & 0.27 & 5.6 & 100 & - \\
\hline \multirow{3}{*}{1131 Int } & $\mathrm{P}$ & 60 & 0.27 & 21.6 & 100 & 85 \\
\hline & $\mathrm{P}$ & 11 & 0.27 & 3.0 & 97 & - \\
\hline & $\mathrm{E}$ & 0.2 & 0.52 & 0.1 & - & - \\
\hline \multirow[t]{2}{*}{$1130 \mathrm{Int}$} & $\mathrm{P}$ & 56 & 0.29 & 16.2 & 98 & 77 \\
\hline & $\mathrm{E}$ & 0.2 & 0.52 & 0.1 & - & - \\
\hline \multirow[t]{2}{*}{1019 Int } & $\mathrm{P}$ & 56 & 0.29 & 16.2 & 99 & 20 \\
\hline & $\mathrm{E}$ & 0.4 & 0.52 & 0.2 & - & - \\
\hline \multicolumn{7}{|c|}{ North Sea } \\
\hline \multirow[t]{2}{*}{1073 Int } & $\mathrm{P}$ & 71.6 & 0.52 & 37.2 & 99 & 66 \\
\hline & $\mathrm{E}$ & 0.4 & 0.52 & 0.2 & - & - \\
\hline 1035 Int & $\mathrm{P}$ & 86 & 0.76 & 65.4 & 100 & 36 \\
\hline $1034 \mathrm{Int}$ & $\mathrm{P}$ & 112 & 0.78 & 87.4 & 100 & 15 \\
\hline \multirow[t]{2}{*}{1055 Int } & $\mathrm{P}$ & 66 & 0.66 & 43.6 & 99 & 14 \\
\hline & E & 0.2 & 1.3 & 0.3 & - & - \\
\hline 1054 Int & $\mathrm{P}$ & 184 & 0.52 & 95.7 & 100 & 18 \\
\hline $1053 \mathrm{Int}$ & $\mathrm{P}$ & 52 & 0.66 & 34.3 & 100 & 4 \\
\hline \multirow[t]{2}{*}{1052 Int } & $\mathrm{P}$ & 14 & 0.52 & 7.3 & 89 & 2 \\
\hline & E & 0.4 & 2.14 & 0.9 & - & - \\
\hline \multirow[t]{2}{*}{1084 Int } & $\mathrm{P}$ & 6 & 0.80 & 4.8 & 23 & 12 \\
\hline & E & 2.0 & 8.2 & 16.4 & - & - \\
\hline \multirow[t]{2}{*}{1082 Int } & $\mathrm{P}$ & 35 & 0.70 & 24.4 & 98 & 3 \\
\hline & $\mathrm{E}$ & 0.2 & 2.1 & 0.4 & - & - \\
\hline \multirow[t]{2}{*}{$1081 \mathrm{Int}$} & $\mathrm{P}$ & 2.3 & 0.70 & 1.6 & 15 & 1 \\
\hline & E & 4.2 & 2.1 & 9.0 & - & - \\
\hline Belt Sea, & Baltic & & & & & \\
\hline 939 Int & $\mathrm{P}$ & 85 & 0.52 & 44.2 & 96 & 10 \\
\hline & $\mathrm{E}$ & 0.8 & 2.1 & 1.7 & - & - \\
\hline 10 & $\mathrm{P}$ & 76 & 0.52 & 39.5 & 99 & - \\
\hline & E & 0.2 & 2.1 & 0.4 & - & - \\
\hline $450 \mathrm{Int}$ & $\mathrm{P}$ & 62 & 0.32 & 19.8 & 85 & 7 \\
\hline & $E$ & 4.8 & 0.70 & 3.4 & - & - \\
\hline 20 & $\mathrm{P}$ & 50 & 0.38 & 19.1 & 100 & - \\
\hline 952 Int & $\mathrm{P}$ & 118 & 0.38 & 45.0 & 100 & 10 \\
\hline 954 Int & $\mathrm{P}$ & 138 & 0.31 & 42.8 & 90 & 7 \\
\hline & $E$ & 5.9 & 0.84 & 4.9 & - & - \\
\hline 15 & $\mathrm{P}$ & 125 & 0.31 & 38.8 & 98 & - \\
\hline & E & 1 & 0.84 & 0.8 & - & - \\
\hline 449 Int & $\mathrm{P}$ & 256 & 0.66 & 169.0 & 95 & 71 \\
\hline & E & 9.1 & 1.0 & 9.1 & - & - \\
\hline 444 Int & P & 446 & 0.35 & 156.1 & 100 & 85 \\
\hline 15 & $\mathrm{P}$ & 177 & 0.45 & 79.7 & 100 & - \\
\hline $431 \mathrm{Int}$ & $\mathrm{P}$ & 301 & 0.38 & 114.4 & 100 & 32 \\
\hline 20 & $\mathrm{P}$ & 12.6 & 0.46 & 5.8 & 100 & - \\
\hline
\end{tabular}


Cyanobacteria of the Synechococcus type dominated the APP populations with respect to both abundance and biovolume (Table 2). Eukaryotes were found at 19 of the 29 stations and dominated at only 2 stations in the German Bight (Stns 1084 \& 1081). Even here the abundance and biovolume of the eukaryotic picoalgae were low (Table 2).

The eukaryotes were generally larger than the cyanobacteria (Table 2). The size of the cyanobacteria varied not only with depth, but also among the different areas. The smallest cells $\left(0.3 \mu \mathrm{m}^{3}\right)$ in the Skagerrak differed significantly ( $\mathrm{p}<0.05, t$-test) from the largest $\left(0.66 \mu \mathrm{m}^{3}\right)$ in the North Sea (Table 3). The mean cell size in the Kattegat, the Baltic and the Belt Sea were between the 2 extremes, but did not differ significantly (Table 3).

Table 3. Biovolume of cyanobacterial picoalgae from the mixed surface layer in Danish coastal waters. Means \pm SD, $\mathrm{n}=$ number of samples

\begin{tabular}{|lccr|}
\hline Area & $\begin{array}{c}\text { Biovolume } \\
\left(\mu \mathrm{m}^{3} \text { cell }^{-1}\right)\end{array}$ & Range & $\mathrm{n}$ \\
\hline Baltic and Belt Sea & $0.42 \pm 0.13$ & $0.32-0.66$ & 7 \\
Kattegat & $0.44 \pm 0.07$ & $0.38-0.52$ & 6 \\
Skagerrak & $0.30 \pm 0.04$ & $0.27-0.38$ & 6 \\
North Sea & $0.66 \pm 0.11$ & $0.52-0.80$ & 10 \\
\hline
\end{tabular}

The calculated APP biomass expressed as chlorophyll varied between 0.18 and $1.8 \mu \mathrm{g} \mathrm{l}^{-1}$ in the mixed surface layer, which amounted to from $1 \%$ to a maximum of $96 \%$ of the total chlorophyll. The distribution of picoalgal biomass with respect to area and productivity (total chlorophyll), and the relative APP contribution to total chlorophyll are summarized in Fig. 2 and Table 2, respectively.

In the Kattegat and Skagerrak the concentrations of APP chlorophyll only varied by a factor of 2 , from 0.3 to 0.5 and from 0.2 to $0.4 \mu \mathrm{g} \mathrm{l}^{-1}$, respectively. However,

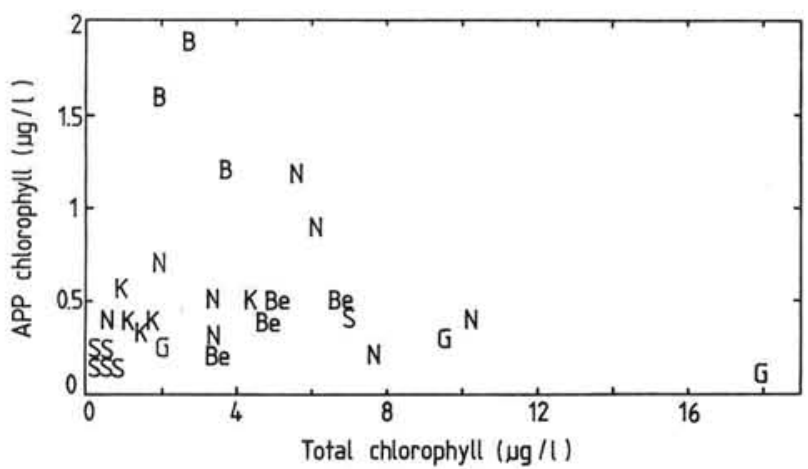

Fig. 2. Calculated picoalgal chlorophyll concentrations versus average total chlorophyll in the mixed surface layers of Danish coastal waters. Abbreviations as in Fig. 1 the relative importance of picoalgae varied from $12 \%$ at Stn 427 in the Kattegat to $96 \%$ at Stn 1133 in the Skagerrak. In the Kattegat the picoalgae accounted for about 20 to $30 \%$ of the autotrophic biomass at most stations, but increased to $60 \%$ at Stn 922 , which had the lowest concentration of total chlorophyll. Very high relative values above $50 \%$ and up to $96 \%$ were found at the low chlorophyll stations in the Skagerrak. At the coastal end of the Skagerrak transect (Stn 1019) and in the Baltic current in the Skagerrak (Stn 1006) total chlorophyll was high and the contribution of APP was low.

In the Belt Sea the concentrations of picoalgae were similar to those in the Kattegat with chlorophyll values about $0.5 \mu \mathrm{g} \mathrm{l}^{-1}$ (Fig. 2). However, due to much higher total chlorophyll the APP contributed only about $10 \%$. Compared with all other stations the absolute values of APP biomass and abundance reached a maximum in the Baltic proper (Arkona Sea) with values above $1 \mu \mathrm{g}$ chl $1^{-1}$ and a relative contribution from 32 to $85 \%$.

In the North Sea 2 different areas could be recognized. At the northern and open water stations, the picoalgal biomass was from 0.5 to $1 \mu \mathrm{g} \mathrm{chl} \mathrm{l}^{-1}$ and about 5 to 10 times higher than that close to the coast and in the German Bight (Fig. 2). Total chlorophyll also showed high variability $\left(0.6\right.$ to $\left.18 \mu \mathrm{g} \mathrm{l}^{-1}\right)$ in the North Sea. Accordingly, the relative contribution of APP varied from above $60 \%$ at the most northern and seaward stations to about $1 \%$ at the most eutrophic station in the German Bight.

A negative relationship between relative picoalgal importance and total algal biomass in the mixed surface layer was best described by a power function (Fig. $3 ; r^{2}=0.79$ ). The exponent found close to -1 , means that the concentration of APP chlorophyll was relatively constant over the range of total chlorophyll. However, the inherent autocorrelation of this relationship and the variability of total and APP chlorophyll indicate that a least squares linear regression

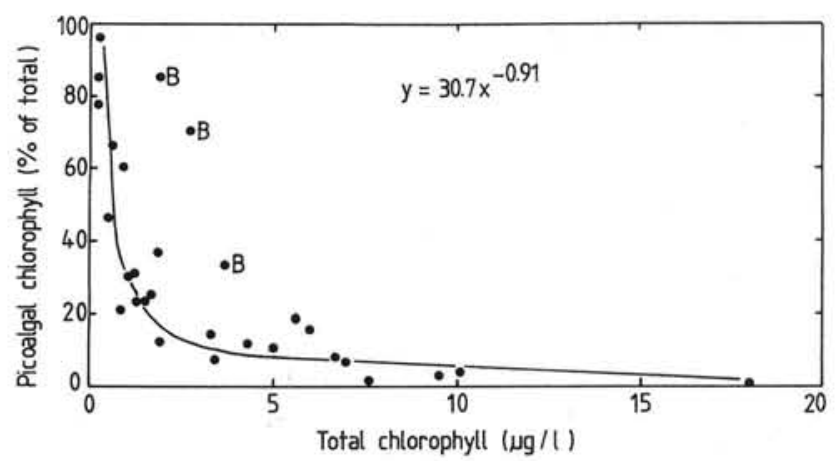

Fig. 3. Relative contribution of calculated picoalgal chlorophyll versus total chlorophyll in the mixed surface layer.

$\mathrm{B}=$ stations in Baltic Sea. Fitted power function is shown 
Fig. 4. Linear regression of calculated picoalgal chlorophyll versus total chlorophyll. Regression: $\log y=-0.435+0.223 \log x$, including all data except Stn $1081\left(18.2 \mu \mathrm{g} \mathrm{chl}^{-1}\right)$

analysis (Model II) of log-transformed absolute values (Sokal \& Rohlf 1981) should be applied. The inclusion of all data in the regression revealed a slope $(0.138 \pm$ $0.194)$ not significantly different from zero $(p>0.1)$ as did all other regressions excluding the low APP values from the Skagerrak and the German Bight and the high values from the Baltic (Fig. 4). The analysis thus showed the picoalgal biomass to be constant at about 0.5 to $0.6 \mu \mathrm{g} \mathrm{chl} 1^{-1}$. It is, however, also apparent that the Skagerrak stations with lowest total chlorophyll concentrations had the lowest APP biomass and that the 3 low-salinity Baltic stations deviated from the rest by their high APP biomass (Fig. 3).

The constant picoalgal biomass in the mixed surface layer over a wide range of total chlorophyll concentrations $\left(0.2\right.$ to $\left.18 \mu \mathrm{g} \mathrm{I}^{-1}\right)$ underlines 2 main features. (1) The dominance of picoalgae was confined to situations with low concentrations of chlorophyll $(<1$ to

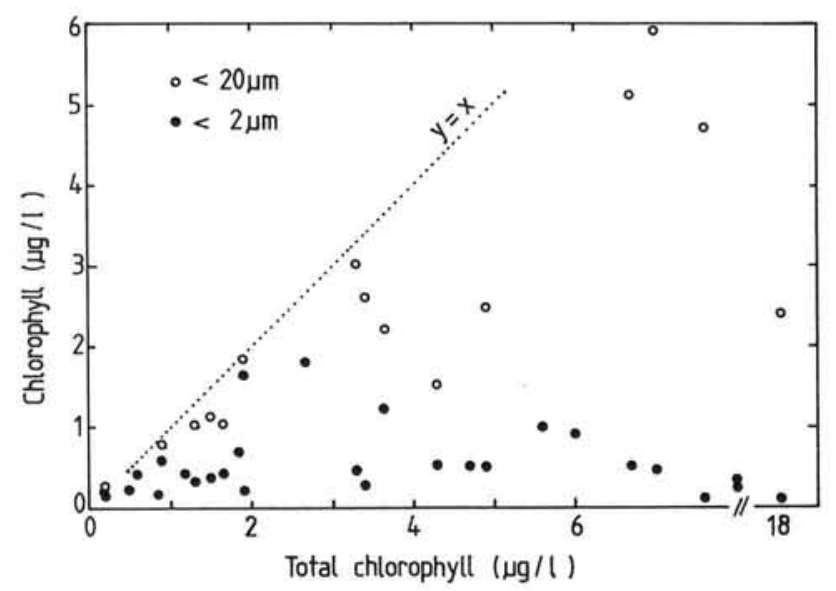

Fig. 5. Concentration of chlorophyll in particles $<2 \mu \mathrm{m}(\bullet)$ and $<20 \mu \mathrm{m}\left({ }^{\circ}\right)$ versus total chlorophyll in Danish coastal waters. The line $y=x$ is shown
$2 \mu \mathrm{g} \mathrm{l}^{-1}$ ). (2) Algal response to higher nutrient input was only seen as increased biomass of the larger species. Thus, data on size-fractionated biomass showed most of the chlorophyll variation to be explained by variation of nanoplankton (Fig. 5). Dominance of netplankton was only found at the innermost German Bight station, at Stn 427 in the Kattegat and at Stn 939 in the Belt Sea (Fig. 5).

\section{DISCUSSION}

\section{Picoalgal abundance and biomass}

The abundance of autotrophic picoplankton (APP) in the mixed surface layer of Danish coastal waters $\left(6 \times 10^{6}\right.$ to $4.5 \times 10^{8}$ cells $\left.1^{-1}\right)$ is within the range normally found during summer in coastal temperate areas (El Hag \& Fogg 1986) and similar to reported cell densities in Kiel Bight (Jochem 1988) and the Baltic Sea (Kuosa 1988). Coccoid and rod-shaped cyanobacteria of the Synechococcus type with phycoerythrin (yellow-orange emission at blue excitation) totally dominated the picoalgal populations. The only 2 exceptions were in the German Bight, where eukaryotes dominated, although at very low cell densities. Eukaryotic picoalgae were found at low densities at most stations, as previously recorded for coastal areas (Glover et al. 1988, Kuosa 1991). Dominance of eukaryotic picoalgae in the marine environment has been reported only from coastal waters of the Tasman Sea (Hall \& Vincent 1990).

The relative importance of picoalgae is often evaluated from the size distribution of chlorophyll (Herbland \& Lebouteiller 1981, Li \& Wood 1988, Raimbault et al. 1988, Hall \& Vincent 1990) or from total phytoplankton biovolumes (Jochem 1988, Kuosa 1988). Size 
fractionation of chlorophyll in the present and some previous studies (Craig 1986, Kennaway \& Edwards 1989, Riemann et al. 1990, Søndergaard 1991) showed, however, high and probably unrealistic APP chlorophyll concentrations compared with calculated chlorophyll values. Furthermore, there was no relationship between measured APP chlorophyll concentrations and biovolumes, a rather common but often unnoticed feature in the literature. Thus, a comparison of picoalgae and total phytoplankton biomass had to rely on measurements of cell abundance and volume and calculations from cell volume to carbon and chlorophyll. The sensitivity of this approach to counting procedures, linear cell dimensions and the conversion factors used warrants further discussion.

The procedure employed could have resulted in too low cell abundance; in particular, loss of chlorophyll a fluorescence by eukaryotes cannot be ruled out (Hall 1991). However, the somewhat conflicting results in the literature concerning fixatives and storage protocols (Bloem et al. 1986, Booth 1987, Kuuppo-Leinikki \& Kuosa 1989, Hall 1991) cannot be used as a guide to evaluate the size of error, if any. Previous tests with lake water samples and cyanobacteria and prochlorophytes from Mediterranean samples (Søndergaard 1991, Wood \& Søndergaard unpubl.) have proved the present protocol satisfactory within a range of $\pm 10 \%$ compared with immediate counting of unpreserved samples.

The sensitivity of biovolume to linear dimensions makes the use of a constant cell size uncertain. The dependence of cell size on depth (Table 2), location (Table 3) and cell type diversity (Kuosa 1988) can make this approach erroneous. The biovolume of cyanobacteria ranged from between 0.27 and $0.8 \mu \mathrm{m}^{3}$ cell $^{-1}$ in the mixed surface layer to a maximum of $2 \mu \mathrm{m}^{3}$ cell $^{-1}$ at $50 \mathrm{~m}$ depth and high nitrate concentrations in the Skagerrak. The cyanobacterial cell sizes were positively related to total chlorophyll, which is an indicator of nutrient load. The eukaryotes were generally larger than the cyanobacteria, an observation also made by Kuosa $(1988,1991)$ and Hall \& Vincent (1990).

The choice of conversion factors from biovolume to chlorophyll is critical, as none of the factors are constant in time and space. From cultures of Synechococcus it is known that growth conditions influence cellular carbon and chlorophyll content (Waterbury et al. 1986), but the variability under natural conditions is largely unknown. Most published conversion factors are measurements from cell cultures (Takahashi et al. 1985, Waterbury et al. 1986) or were estimated from empirical equations extrapolated to picoalgal volumes, e.g. the formula of Strathmann (1967). For the cyanobacteria we have used C:vol. and C:chl. factors of $250 \mathrm{fg} \mathrm{C} \mu \mathrm{m}^{-3}$ and $22.5 \mu \mathrm{gC} \mu \mathrm{g} \mathrm{chl} \mathrm{C}^{-1}$, respectively
(Takahashi et al. 1985, Geider 1987, Ray et al. 1989 ). Although in situ estimates can easily be biased by detrital carbon, Takahashi et al. (1985) and Ray et al. (1989) found mean C:chl values for cyanobacteria of 32 and 20, respectively. One further argument for the chosen factors is that they give a chl. : vol. ratio of $11 \mathrm{fg}$ chl $\mu \mathrm{m}^{-3}$, which is in close agreement with the empirical factor of about 10 that can be calculated from the data of Hall \& Vincent (1990).

If we combine the potential errors from counting statistics ( $\pm 10 \%$ ), biovolume estimations (5 to $10 \%$ $\mathrm{CV}$ on each slide preparation) and take the range of conversion factors between 7 to 11 on a chl:vol. basis, the calculated APP chlorophyll would range within a factor of \pm 1.6 . The values of APP chlorophyll presented in this study are probably at the upper range due to the use of a high concentration of chlorophyll.

\section{Picoalgal importance and food web structure}

The biological structure in oligotrophic oceanic waters and in stratified nutrient-depleted areas is characterized by the dominance of small organisms, collectively known as the microbial loop (Azam et al. 1983, Cushing 1989, Kiørboe et al. 1990). Under these conditions production is regulated by the quasi steady state internal regeneration of nutrients. Picoalgae and small autotrophic flagellates with high growth rates and low biomasses are the main primary producers (Laws et al. 1984, Kuosa 1988, Cushing 1989). Accordingly, the relative importance of picoalgae should be an indicator of nitrate loading either by horizontal or upward transport. However, in regions with vertical upwelling this is not necessarily the case, as found by Hall \& Vincent (1990).

Turbulent hydrodynamics such as total mixing, frontal systems and storm events give rise to new production based on nitrate input to the euphotic zone. Development and dominance of larger algae is a characteristic feature of new production, which creates the direct link to secondary production in the classical grazer food chain (Cushing 1989, Kiørboe \& Nielsen 1990). There seems to be a continuum between the 2 extremes. In the oligotrophic oceans and especially in tropical and subtropical regions the microbial loop dominates, while seasonal and temporal changes in the dominance of small and large algae depending on stratification and mixing events can be expected in temperate and coastal environments (Kiørboe et al. 1990). The influence of nutrient discharge from land must also be considered.

A continuum with respect to relative picoalgal importance was observed in the present study (Fig. 3). If dominance by the microbial loop is defined as more 
than $50 \%$ of the total chlorophyll in the picoplankton size fraction, 7 of 29 stations can be included in such a category; 3 in the dome area in the Skagerrak, 1 in the North Sea, 1 in the Kattegat and 2 in the Baltic proper. Stn 431 is in hydrographic terms placed in the Belt Sea of Denmark, however the salinity and high picoalgae abundance clearly disclosed the Baltic origin of the mixed surface water (Table 1).

Over a total chlorophyll concentration range of almost 2 orders of magnitude (Table 1) the concentration of picoplankton chlorophyll only varied 1 order of magnitude and statistically could be considered constant within a range of 0.5 to $0.6 \mu \mathrm{g} \mathrm{chl} \mathrm{l}^{-1}$ (Figs. 4 \& 5). At total chlorophyll values above $1 \mu \mathrm{g} \mathrm{l}^{-1}$, the nanoplankton ( 2 to $20 \mu \mathrm{m}$ ) and occasionally microplankton ( $>20 \mu \mathrm{m}$ ) made up an increasing fraction of the total (Fig. 5). A similar pattern was compiled for oceanic data by Raimbault et al. (1988). They found absolute maximal chlorophyll concentrations for the size fractions $<1$ and $<3 \mu \mathrm{m}$ to be 0.5 and $1.3 \mu \mathrm{g} \mathrm{l^{-1 }}$, respectively. The conclusion must be that picoalgae do not accumulate large biomass in surface waters and generally only dominate primary production in nutrient depleted waters, although exceptions may be found (Hall \& Vincent 1990).

In lakes, high peak values of 3 to $5 \mu \mathrm{g} \mathrm{I}^{-1}$ of picoalgal chlorophyll have been reported (Søndergaard 1991, Weisse \& Schweizer 1991); however, average summer values were at or below $1 \mu \mathrm{g}^{-1}$ (Stockner 1988) and independent of lake trophic status (Søndergaard 1991). Thus, 'the remarkable constancy of numbers of planktonic bacteria' (Wright 1988) is repeated by the picoalgae, where the number and biomass seem remarkably constant on a global scale.

A constant or almost constant abundance and biomass during the growing season can only be explained if growth and loss rates are equal on a short-term scale, i.e. that a steady-state like situation is prevailing. Although substrate limitation of picoalgal growth rates cannot be excluded in the most nutrient-depleted areas, theoretical considerations based on surface/ volume ratios and diffusion rates (Raven 1986) make substrate limitation unlikely. Empirical evidence of almost optimal growth rates of 1 to $2 \ln$ units $\mathrm{d}^{-1}$ (Laws et al. 1984, Kudoh et al. 1990), even at very low light availability (Fogg 1986, Kuosa 1988), points to the loss processes as the controlling agent. Sedimentation of picoalgae can be considered zero (Fogg 1986), so maintenance respiration, grazing and cell lysis must balance growth. Our knowledge concerning respiration and cell lysis is meager, so grazing by nanoflagellates, ciliates, and perhaps other organisms (Kuosa 1988, Weisse 1988, Kudoh et al. 1990), which are known to control planktonic bacteria (Wright 1988), must at present be considered the most prominent pro- cess controlling picoalgal abundance. In oceanic surface waters off Japan, Kudoh et al. (1990) showed Synechococcus growth rates and their grazing mortality by ciliates and colourless flagellates to balance. Similar results were obtained by Weisse (1988) in Lake Constance (Germany) and were also suggested for picoalgal control in the northern Baltic Sea, although flagellate grazing rates during summer were lower than cyanobacterial growth rates (Kuosa 1991).

Mathematical models have been used to describe steady-state situations for phytoplankton growth (Thingstad \& Sakshaug 1990) and planktonic microbial food webs (Wright 1988). The data on picoalgae from the present investigation and from others (Raimbault et al. 1988) actually fit a 2-layered ecosystem model based on Lotka-Volterra equations, where small algae dominate at very low inorganic nutrient availability (Thingstad \& Sakshaug 1990). Inorganic nutrients limit biomass at extremely low concentrations, but grazing is the controlling agent at increasing nutrient enrichment, where nutrients no longer limit growth rates and are accumulating in the solution. The grazer control of picoalgae by protozoans at this stage - or other density-dependent control mechanisms - now permits other and eventually larger algae to explore the surplus of inorganic nutrients. The steady-state model is of course a simplification of nature, as also stated by Thingstad \& Sakshaug (1990). However, it offers a conceptual frame to explain why and how picoalgae dominate the phytoplankton during low mixing and low nutrient input, and why larger algae, not grazed to any great extent by nanoflagellates and ciliates, become dominating during periods of increased nutrient input.

The above general and theoretical explanation leaves the question open as to why picoalgal biomass was about 3 times higher in the Baltic than in the other areas. With respect to salinity the Baltic is brackish and transient between freshwater and the marine environment. Recently, Kuosa $(1990,1991)$ observed in the Baltic a short-duration Synechococcus peak of $1.6 \times$ $10^{9}$ cells $1^{-1}$. Grazer control in brackish environments, as opposed to oceanic areas, might operate on a different time scale and perhaps with a lower affinity constant for prey. The same might apply to freshwater, where very large but short duration peaks of picoalgae can also occur (Weisse 1988, Stockner \& Shortreed 1989, Søndergaard 1991).

Acknowledgements. Part of this study was supported by the Danish Natural Science Research Council (M.S.). We appreciate the logistic help by the crew aboard 'Gunnar Thorson' and technical assistance by Gitte Jacobsen and Pernille Greve. Valuable suggestions from Kaj Sand-Jensen and the referees are much appreciated. 


\section{LITERATURE CITED}

Azam, F., Fenchel, T., Field, J. G., Gray, J. S., Meyer Reil, L.-A., Thingstad, F. (1983). The ecological role of water column microbes in the sea. Mar. Ecol. Prog. Ser. 10: 257-263

Bloem, J., Bär-Gilissen, M.-J. B., Cappenberg, T. E. (1986). Fixation, counting, and manipulation of heterotrophic nanoflagellates. Appl. environ. Microbiol. 52: 1266-1272

Booth, B. C. (1987). The use of autofluorescence for analysing oceanic phytoplankton communities. Botanica mar. 30: 101-108

Booth, B. C. (1988). Size classes and major taxonomic groups of phytoplankton at two locations in the subarctic Pacific Ocean in May and August, 1984. Mar. Biol. 97: 275-286

Caron, D. A. (1983). Technique for enumeration of heterotrophic and photottrophic nanoplankton, using epifluorescence microscopy, and a comparison with other procedures. Appl, environ. Microbiol. 46: 491-498

Caron, D. A., Pick, F. R., Lean, D. R. S. (1985). Chroococcoid cyanobacteria in Lake Ontario: vertical and seasonal distribution during 1982. J. Phycol. 21: 171-175

Chisholm, S. W., Ilsen, R. J., Zettler, E. R., Goerecke, R., Waterbury, J. B., Welschmeyer, N. A. (1988). A novel freeliving prochlorophyte abundant in the oceanic euphotic zone. Nature, Lond. 334: 340-344

Craig, S. R. (1986). Picoplankton size distributions in marine and fresh waters: problems with filter fractionation studies. FEMS Microb. Ecol. 38: 171-177

Cushing, D. H. (1989). A difference in structure between ecosystems in strongly stratified waters and in those that are only weakly stratified. J. Plankton Res. 11: 1-13

El Hag, A. G. D., Fogg, G. E. (1986). The distribution of coccoid blue-green algae (Cyanobacteria) in the Menai Straits and the Irish Sea. Br. phycol. J. 21: 45-54

Fogg, G. E. (1986). Picoplankton. Proc. R. Soc. Lond. B 228: $1-30$

Geider, R. J. (1987). Light and temperature dependence of the carbon to chlorophyll a ratio in microalgae and cyanobacteria: implications for physiology and the growth of phytoplankton. New Phytol. 106: 1-34

Glover, H. E., Prèzelin, B. B., Campbell, L., Wyman, M. (1988). Pico- and ultraplankton Sargasso Sea communities: variability and comparative distribution of Synechococcus spp. and algae. Mar. Ecol. Prog. Ser. 49: 127-139

Grasshoff, K., Ehrhardt, M., Kremling, K. (eds.) (1983). Methods of seawater analysis, 2nd edn. Verlag Chemie, Weinheim

Hall, J. A. (1991). Long-term preservation of picophytoplankton for counting by fluorescence microscopy. Br. phycol. J. 26: 169-174

Hall, J. A., Vincent, W. F. (1990). Vertical and horizontal structure in the picoplankton communities of a coastal upwelling system. Mar. Biol. 106: 465-471

Helsinki Commission (1988). Guidelines for the Baltic Monitoring Programme for the Third Stage; Part D. Biological Determinands. Baltic Sea Environment Proceedings, No. 27 D, Baltic Marine Environment Protection Commission, Government Printing Centre, Helsinki

Herbland, A., Lebouteiller, A. (1981). The size distribution of phytoplankton and particulate organic matter in the Equatorial Atlantic Ocean, importance of ultraseston and consequences. J. Plankton Res. 3: 659-673

Jespersen, A.-M., Christoffersen, K. (1987). Measurement of chlorophyll-a from phytoplankton using ethanol as extraction solvent. Arch. Hydrobiol. 109: 445-454

Jochem, F. (1988). On the distribution and importance of picocyanobacteria in a boreal inshore area (Kiel Bight, Western Baltic). J. Plankton Res. 10: 1009-1022

Joint, I. R. (1986). Physiological ecology of picoplankton in various oceanographic provinces. Can. Bull. Fish. Aquat. Sci. 214: 287-309

Kana, T. M., Glibert, P. M. (1987). Effect of irradiances up to $2000 \mu \mathrm{E} \mathrm{m}^{-2} \mathrm{~s}^{-1}$ on marine Synechococcus WH7803. I. Growth, pigmentation, and cell composition. Deep Sea Res. 34: 479-495

Kennaway, G. M. A., Edwards, G. (1989). Seasonal and vertical distribution of picoplankton in Llyn Padarn, Gwynedd. Br. phycol. J. 24: 375-384

Kiørboe, T., Kaas, H., Kruse, B., Møhlenberg, F., Tiselius, P., Aertebjerg, G. (1990). The structure of the pelagic food web in relation to water column structure in the Skagerrak. Mar. Ecol. Prog. Ser. 59: 19-32

Kiørboe, T., Nielsen, T. G. (1990). Effect of wind stress on vertical water column structure, phytoplankton growth and productivity of planktonic copepods. In: Barnes, M. Gibson, R. N. (eds.) Trophic interactions in the marine environment. Proc. 24th Eur. Mar. Biol. Symp. Aberdeen Univ. Press, Aberdeen, p. 28-40

Kudoh, S., Kanda, J., Takahashi, M. (1990). Specific growth rates and grazing mortality of chroococcoid cyanobacteria Synechococcus spp. in pelagic surface waters in the sea. J. exp. mar. Biol. Ecol. 142: 201-212

Kuosa, H. (1988). Occurrence of autotrophic picoplankton along an open sea -inner archipelago gradient in the Gulf of Finland, Baltic Sea. Ophelia 28: 85-93

Kuosa, H. (1990). Subsurface chlorophyll maximum in the northern Baltic sea. Arch. Hydrobiol. 118: 437-447

Kuosa, H. (1991). Picoplanktonic algae in the northern Baltic Sea: seasonal dynamics and flagellate grazing. Mar. Ecol. Prog. Ser. 73: 269-276

Kuuppo-Leinikki, P., Kuosa, H. (1989). Preservation of picoplanktonic cyanobacteria and heterotrophic nanoflagellates for epifluorescence microscopy. Arch. Hydrobiol. 114: $631-636$

Laws, E. A., Redalje, D. G., Haas, L. W., Bienfang, P. K., Eppley, R. W., Harrison, W. G., Karl, D. M., Marra, J. (1984). High phytoplankton growth and production rates in oligotrophic Hawaiian coastal waters. Limnol. Oceanogr. 29: 1161-1169

Li, W. K., Wood, A. M. (1988), Vertical distribution of North Atlantic ultraphytoplankton: analysis by flow cytometry and epifluorescence microscopy. Deep Sea Res. 35: 1615-1638

May, K. R. (1965). A new graticule for particle counting and sizing. J. sci. Instrum. 42: 500-501

Olson, R. J., Chrisholm, S. W., Zettler, E. R., Armbrust, E. V. (1990). Pigment, size, and distribution of Synechococcus in the North Atlantic and Pacific Oceans. Limnol. Oceanogr. 35: $45-58$

Raimbault, P., Rodier, M., Taupier-Letage, I. (1988). Size fractionation of phytoplankton in the Ligurian Sea and the Algerian Basin (Mediterranean Sea): size distribution versus total concentration. Mar. microb. Food Webs 3: 1-7

Ray, R. T., Haas, L. W., Sieracki, M. E. (1989). Autotrophic picoplankton dynamics in a Chesapeake Bay sub-estuary. Mar. Ecol. Prog. Ser. 52: 273-285

Raven, J. A. (1986). Physiological consequences of extremely small size for autotrophic organisms in the sea. Can. Bull. Fish. Aquat. Sci. 214: 1-70

Riemann, B., Sørensen, H. M., Bjørnsen, P. K., Horsted, S. J., Jensen, L. M., Nielsen, T. G., Søndergaard, M. (1990). Carbon budgets of the microbial foodwebs in estuarine enclosures. Mar. Ecol. Prog. Ser. 65: 159-170 
Sieburth, J. McN., Smetacek, V., Lenz, J. (1978). Pelagic ecosystem structure: heterotrophic compartments of the plankton and their relationship to plankton size fractionation. Limnol. Oceanogr. 23: 1256-1263

Sokal, R. R., Rohlf, F. J. (1981). Biometry, 2nd edn. Freeman and Co, New York

Søndergaard, M. (1991). Phototrophic picoplankton in temperate lakes: seasonal abundance and importance along a trophic gradient. Int. Rev. ges. Hydrobiol. 76: 505-522

Stockner, J. G. (1988). Phototrophic picoplankton: an overview from marine and freshwater ecosystems, Limnol, Oceanogr. 33: 765-775

Stockner, J. G., Antia, N. J. (1986). Algal picoplankton from marine and freshwater ecosystems: a multidisciplinary perspective. Can. J. Fish. Aquat. Sci. 43: 2472-2503

Stockner, J. G., Shortreed, K. S. (1989). Algal picoplankton production and contribution to food-webs in oligotrophic British Columbia lakes. Hydrobiologia 173: 151-166

Strathmann, R. R. (1967). Estimating the organic carbon content of phytoplankton from cell volume or plasma volume. Limnol. Oceanogr. 12: 411-418

Svansson, A. (1984). Hydrographic features of the Kattegat. Rapp. Pr.-v. Réun. Cons. int. Explor. Mer 185: 78-90

This article was submitted to the editor
Takahashi, M., Kikuchi, K., Hara, Y. (1985). Importance of picocyanobacteria biomass (unicellular, blue-green algae) in the phytoplankton population of the coastal waters off Japan. Mar. Biol. 89: 63-69

Thingstad, T. F., Sakshaug, E. (1990). Control of phytoplankton growth in nutrient recycling ecosystems. Theory and terminology. Mar. Ecol. Prog. Ser. 63: 261-272

Waterbury, J. B., Watson, S. W., Guillard, R. R. L., Brand, L. E. (1979). Widespread occurrence of a unicellular, marine, planktonic cyanobacterium. Nature, Lond. 277: 293-294

Waterbury, J. B., Watson, S. W., Valois, F. W., Franks, D. G. (1986). Biological and ecological characterization of the marine unicellular cyanobacterium Synechococcus. Can. Bull. Fish. Aquat. Sci. 214: 71-120

Weisse, T. (1988). Dynamics of autotrophic picoplankton in Lake Constance. J. Plankton Res. 10: 1179-1188

Weisse, T., Schweizer, A. (1991). Seasonal and interannual variation of autotrophic picoplankton in a large prealpine lake (Lake Constance). Verh. int. Ver. theor. angew. Limnol. 24: 821-825

Wright, R. T. (1988). A model for short-term control of the bacterioplankton by substrate and grazing. Hydrobiologia 159: $111-117$

Manuscript first received: July 25, 1991

Revised version accepted: December 5, 1991 